\title{
PEMBERDAYAAN MASYARAKAT MELALUI PROGRAM BUKANNAMBA: BUDIDAYA IKAN DAN TANAMAN DENGAN TIMBA DI ERA PANDEMI
}

\author{
Thoriq Al Anshori'1, Irmadani Dwi Putri Jayanti², Nia Septiani², Nur Fadhila \\ Muyassaro ${ }^{2}$ \\ ${ }^{1}$ Fakultas Agama Islam, Universitas Islam Malang \\ ${ }^{2}$ Fakultas Pertanian, Universitas Islam Malang
}

*korespondensi email: thoriqalanshori@unisma.ac.id

\begin{abstract}
ABSTRAK
Situasi pandemi saat ini merupakan situasi yang harus dihadapi oleh seluruh masyarakat dunia termasuk masyarakat Indonesia. Ketahanan pangan merupakan salah satu penunjang kehidupan utama yang dalam masa pandemi Covid-19 ini harus tetap dipertahankan. Dibutuhkan pemberdayaan masyarakat yang inovatif dan prospek guna memenuhi kebutuhan ini, salah satunya adalah kebutuhan sayur dan protein. Dalam rangka meningkatkan dan menunjang ketahanan pangan warga dalam menguatkan ketahaan pangan yaitu melalui program BUKANNAMBA (Budidaya Ikan Dan Tanaman dengan Timba). BUKANNAMBA merupakan salah satu kegiatan mahasiswa-mahasiswi KSM Tematik UNISMA 2021 di desa Racitengah Sidayu Gresik dengan mtimbaikan pendampingan pertanian sistem aquaponik dengan nama BUKANNAMBA, yaitu sebuah sistem pertanian hasil modifikasi berupa pembudidayaan ikan lele sederhana dengan menggabungkan sistem pertanian hidroponik dengan budidaya akuakultur dengan memanfaatkan media sederhana berupa timba. Metode yang digunakan adalah pendampingan dengan melalui beberapa tahap; Persiapan, Pelaksanaan dan evaluasi. Hasil dari pendampingan ini yaitu warga desa Racitengah mampu mengadakan BUKANNAMBA secara mandiri di rumah masing-masing, di mana kebanyakan warga memang sebelumnya mengalami kesulitan jika ingin menciptakan ketahanan pangan melalui pertanian dan perikanan karena keterbatasan lahan. Sehingga dengan kegiatan ini masyarakat dapat menciptakan ketahanan pangan yang kuat secara mandiri dan berkelanjutan.
\end{abstract}

Kata Kunci: pemberdayaan; BUKANNAMBA; ketahanan pangan, pandemi

\section{PENDAHULUAN}

Ketahanan pangan merupakan salah satu penunjang kehidupan urgen yang dalam masa pandemi Covid-19 ini harus tetap dipertahankan secara berkelanjutan. Kebutuhan pokok sehari-hari semua orang harus tetap dipenuhi ditengah situasi pandemi ini. Oleh karena itu dibutuhkan sebuah solusi untuk mencukupi kebutuhan hidup di tengah pandemi, untuk itulah melalui KSM-Tematik mahasiswa UNISMA menjalankan program kerja BUKANNAMBA sekaligus menciptakan alternatif solusi untuk ketahanan pangan di masa pandemi membuat program kerja yaitu pembuatan Bukannamba (budidaya ikan dan Tanaman dalam tamba) yang dilaksanakan di Desa Racitengah, Kecamatan Sidayu, Kabupaten Gresik. Dibutuhkan pendampingan masyarakat yang baru guna memenuhi kebutuhan pangan, salah satunya adalah kebutuhan sayur dan protein. Salah kegiatan yang 
dapat dilakukan guna membantu masyarakat dalam ketahaan pangan yaitu melalui program BUKANNAMBA (Aswatini et al., 2008; Habiburrohman, 2018).

BUKANNAMBA adalah diantara alternatif untuk menanam sayuran sekaligus membudidayakan ikan dalam satu wadah atau timba (Ariyanto et al., 2014; Hanifah, 2021). Tanaman khususnya sayur membutuhkan nutrisi untuk tumbuh yang disuplai dari kotoran ikan sebagai sumber unsur hara (Rhofita \& Chana AW, 2019). Keuntungan bagi ikan adalah memperoleh filter vegetasi alami yang akan mengurai zat racun sekaligus menyuplai oksigen bagi ikan. Dengan hubungan timbal balik ini akan menjadi simbiosis mutualisme yang saling menguntungkan. Metode ini memiliki keunggulan jika dibandingkan dengan sistem konvensional, yang salah satunya adalah penggunaan air sebagai pengganti media tanah dalam praktiknya, sehingga lebih praktis untuk diterapkan (Anwar, 2019; Khotimah et al., 2021; Machfudz et al., 2018).

Sistem ini lebih dikenal dengan nama aquaponik yang sudah sangat berkembang yang secara luas dipraktikan oleh masyarakat sebagai upaya pemenuhan sayuran dan sumber protein sebagai bahan pangan sehari-hari. Secara sederhana, aquaponik dapat digambarkan sebagai penggabungan antara sistem budidaya akuakultur (budidaya ikan) dengan hidroponik (budidaya tanaman/sayuran tanpa media tanah). Sistem ini mengadopsi sistem ekologi pada lingkungan alamiah, dimana terdapat hubungan simbiosis mutualisme antara ikan dan tanaman (Setijaningsih \& Umar, 2015; Walimbo et al., 2017).

Dengan latar belakang mata pencaharian mayoritas penduduk desa Racitengah sebagai petani, Ptimbadayaan masyarakat melalui pendampingan sistem BUKANNAMBA ini diharapkan dapat menjadi alternatif untuk dikembangkan dengan memadukan antara sistem pertanian hidroponik dengan sistem akuakultur guna meningkatkan sumber daya manusia sekaligus menumbuhkan kesadaran, kemauan, dan kemampuan masyarakat dalam mengenali dan meningkatkan kesejahteraan masyarakat Desa Racitengah untuk pemenuhan kebutuhan pangan.

Kegiatan Progrm BUKANNAMBA dipelopori oleh mahasiswa-mahasiswi KSMTematik UNISMA 2021 kelompok 95. Kegiatan ini berlangsung dalam 5 Hari, yang di mulai dari tanggal 20 - 26 Agustus 2021. Kegiatan Pendampingan ini dimulai setiap pagi sampai siang hari. Karena kegiatan KSM tematik kali ini berbasis domisili, kegiatan ini dapat dipastikan akan terus berkelanjutan mengingat mahasiswa-mahasiswi adalah penduduk asli desa Racitengah Sidayu Gresik. Berbagai tanggapan postif pun diterima oleh pelaksana kegiatan.

\section{METODE}

Metode yang digunakan dalam kegiatan ini yaitu dengan metode pendampingan secara langsung. Di mana dalam pelaksanaannya terdapat beberapa tahapan, yaitu tahap persiapan, tahap pendampingan, tahap praktik lapangan dan tahap evaluasi kegiatan

\section{Tahap persiapan}

Pada tahap ini hal yang dilakukan yaitu pertama, melakukan survei dan komunikasi kepada Kepala Sekretaris Desa dan menanyakan seputar kegiatan pertanian di desa Racitengah, setelah itu dilakukan persiapan seperti meminta izin pengadaan kegiatan kepada ketua kelompok wanita tani dan persiapan rancangan kegiatan.

\section{Tahap Pendampingan}

Sosialisasi dilakukan dengan maksud untuk memaparkan Kegiatan dari BUKANNAMBA yang telah dirancang di depan warg desa Racitengah untuk mengenalkan sekaligus menambah pengetahuan warga desa. Pendampingan dilakukan secara langsung dengan jumlah peserta yang dibatasi dan bertempat dii sekitar rumah 
kelompok tani wanita di Desa Racitengah, Mendiskusikan lokasi dan jadwal pelaksanaan program kegiatan ptimbadayaan masyarakat.

\section{Tahap Praktik}

Pada tahap ini masyarakat melakukan praktik langsung BUDI DAMBER yang didampingi oleh mahasiswa KSM. Masyarakat akan praktik untuk menyiapkan arang sekam yang digunakan sebagai media tanam, kemudian melubangi gelas minum plastic, dan melakukan persiapan timba untuk tempat ikan lele.

\section{Tahap Evaluasi}

Setelah selesai pelaksanaan kegiatan, masyarakat akan bisa melihat perkembangan dari BUKANNAMBA yang dilakukan, dan meninjau kualitas budidaya ikan yang dilakukan di dalam timba serta kualitas sayuran secara hidroponik yang dihasilkan setelah tim pelaksana melaksanakan kegiatan ptimbadayaan kepada masyarakat serta mtimbai arahan bagaimana memulai wirausaha mandiri.

\section{HASIL DAN PEMBAHASAN}

Program KSM tematik berbasis domisili dan keilmuan yang dilakukan mahasiswa UNISMA tetap menerapkan protokol Kesehatan yang sudah di tetapkan oleh pemerintah desa setempat yaitu menjaga jarak, memakai masker dan mencuci tangan dalam melakukan berbagai aktivitas di lapangan. Kegiatan pendampingan BUKANNAMBA diawali dengan observasi yang dilakukan untuk mendapatkan informasi mengenai potensi dari desa Racitengah dan hal yang dapat dikembangkan pendampingan ini masyarakat dapat akhirnya bisa membudayakan ikan serta tanaman dipekarangan rumah yang sempit dan berkelanjutan. Sehingga dengan kegiatan ini Masyarakat dapat menciptakan ketahanan pangan yang kuat.

Proses observasi dilakukan dengan mengunjungi Kepala desa dan melakukan wawancara sekaligus meminta izin untuk melakukan kegiatan ptimbadayaan masyrakat di desa Racitengah. Setelah mendapatkan izin dari kepala desa kemudian melakukan penentuan waktu dan lokasi pelaksanaan pendampingan. Sebelum kegiatan inti dilaksanakan dari Tim KSM terlebih dahulu melakukan Pendampingan yang bertempat di rumah ketua kelompok wanita tani. Kegiatan ini dihadiri oleh 10 peserta. Kegiatan sosialisasi diawali dengan penyampaian sambutan dari Ketua Kelompok KSM, yang kemudian dilanjutkan dengan pemaparan materi dari mahasiswa KSM mengenai pengenalan sederhana BUKANNAMBA yang merupakan bentuk inovasi dari hidroponik.

Pada saat pemaparan dari Tim KSM menawarkan dua pilihan pendampingan, yaitu pendampingan Vertikultur biasa dan hidroponik dengan model BUKANNAMBA. Tim KSM menjelaskan kepada masyarakat bahwa untuk penggunaan Hidroponik model BUKANNAMBA dapat dilaksanakan lebih mudah dan sederhana, karena tidak memerlukan banyak perawatan yang begitu ekstra layaknya hidroponik biasa. Selain itu, BUKANNAMA dapat lebih menghemat biaya dan hasil yang diperoleh saat panen tidak hanya sayur, tetapi juga ikan lele. Kegiatan pendampingan dilakukan pada tanggal 20 Agustus 2021, dimana dalam kegiatannya diikuti oleh 10 orang peserta dari kelompok wanita tani. Pada saat kegiatan pendampingan dilaksanakan kami dari Tim KSM. 


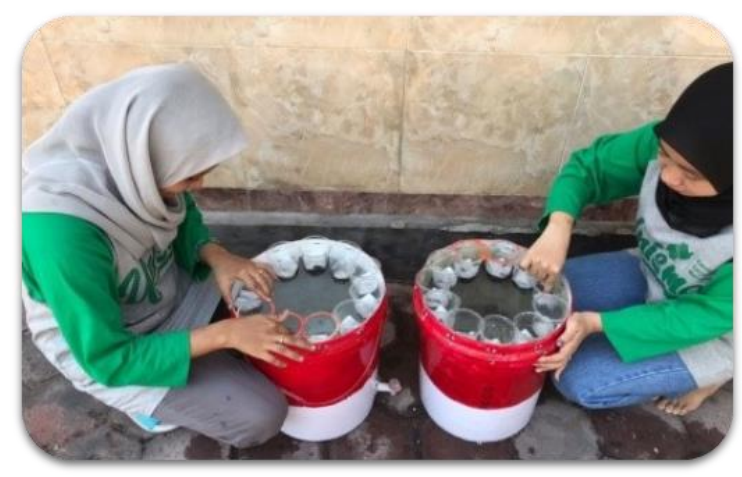

Gambar 1. Kegiatan Budikdamber

Kegiatan pendampingan diawali dengan sedikit penyampaian materi tentang BUKANNAMBA dari Tim KSM-Tematik, kemudian warga memulai mempraktekan seperti mempersiapkan alat dan bahan, kemudian melubangi gelas plastic menggunakan paku panas. Selanjutnya dari Tim KSM melakukan demonstrasi tentang bagaimana tata cara untuk membuat media tanam dari arang sekam. Setiap warga kemudian mencoba untuk mempraktekannya dan memasukkan media tanam ke dalam gelas plastik. Dalam pendampingan ini dihasilkan 5 timba yang telah diisi dengan ikan lele dan dari hasil tanaman sayuran yang telah disiapkan kemudian diletakkan di atas timba dimana pada tutupnya telah dilubangi.

Kegiatan pendampingan masyarakat ini dilanjutkan dengan kegiatan evaluasi terhadap budidaya ikan dalam timba yang telah diberikan kepada masyarakat. Terdapat beberapa kendala yang ditemukan yaitu, beberapa kali ditemukan bahwa ikan lele yang ada di dalam timba mati dan penemptan timba yang kurangtepat karena terlalu terpapar sinar matahari, sehingga tanaman kangkung kurang subur. Namun, hal tersebut dapat diatasi dengan lebih memperhatikan pakan dari ikan lele dan memindahkan timba ke tempat dengan pencahayaan yang lebih tepat Sehingga pada minggu ketiga dapat dilakukan pemanenan sayuran kangkung dan Sawi.

Dari tahapan evaluasi ini diharapkan dengan adanya pendampingan ini masyarakat terus mengembangkan dan melanjutkan program BUKANNAMBA, untuk kritik dan saran dari Program yang dilakukan KSM-Tematik UNISMA, Bahwa antusias warga untuk pendampingan dan kesdaran pertanian berkelanjutan masih kurang, dan untuk saran Kegiatan pendampingan BUKANNAMBA diharapkan tidak hanya dilakukan di RT 01 RW 01 Desa Racitengah tetapi di lokasi lain agar Budidaya ini menjadi solusi penagangan ketahanan pangan di masa pandemi.

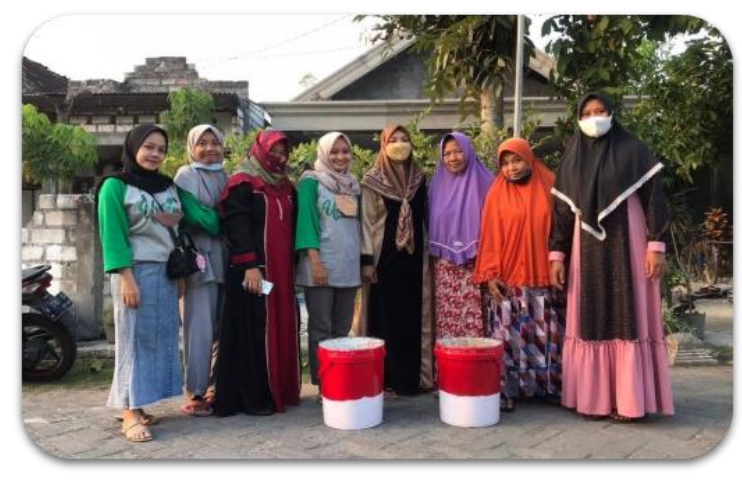

Gambar 2. BUDIKDAMBER 


\section{KESIMPULAN}

Dalam rangka membangun upaya kemandirian masyarakat di bidang ekonomi pertanian atau ketahanan pangan. Oleh karena itu dibutuhkan sebuah solusi untuk mencukupi kebutuhan hidup di tengah pandemi, untuk itulah melalui KSM-Tematik mahasiswa UNISMA menjalankan program kerja BUKANNAMBA sekaligus menciptakan alternatif solusi untuk ketahanan pangan di masa pandemi membuat program kerja yaitu pembuatan Bukannamba (budidaya ikan dan Tanaman dalam tamba) yang dilaksanakan di Desa Racitengah, Kecamatan Sidayu, Kabupaten Gresik. Pendampingan ini cocok dan mampu dilakukan oleh masyarakat Desa Racitengah. Metode yang digunakan dalam kegiatan ini yaitu dengan metode pendampingan secara langsung. Di mana dalam pelaksanaannya terdapat beberapa tahapan, yaitu: tahap persiapan, tahap pendampingan, tahap praktik dan tahap evaluasi kegiatan.

Hasil dari pendampingan ini adalah warga mampu memahami cara bertanam dengan sistem aquaponik ini serta mampu mempraktekkan secara mandiri. Selain itu, penggunaan BUKANNAMBA ini dapat lebih menghemat biaya dan hasil yang diperoleh saat panen tidak hanya sayur, tetapi juga ikan lele. Dalam tiga minggu telah dapat dilakukan pemanenan sayuran

\section{UCAPAN TERIMA KASIH}

Pengabdi mengucapkan Terima Kasih kepada Pemerintahan Desa Racitengah, yang sudah memeberikan izin untuk melakukan pendampingan ini. Dan Terima Kasih Kepada masyarakat Desa Raci Tengah, Kecamatan Sidayu, Kabupaten Gresik yang telah m timbaikan kesempatan dan dukungan kepada peneliti untuk melakukan dan menyelesaikan kegiatan pendampingan masyarakat ini.

\section{DAFTAR RUJUKAN}

Anwar. (2019). Budidaya Ikan Lele di Desa gending.

Ariyanto, Rachman, I., \& Toknok, B. (2014). Kearifan Masyarakat Lokal dalam Pengelolaan Hutan di Desa Rano Kecamatan Balaesang Tanjung Kabupaten Donggala. Warta Rimba, $2(2)$ 84-91. http://jurnal.untad.ac.id/jurnal/index.php/WartaRimba/article/view/3618

Aswatini, Noveria, M., \& Fitranita. (2008). Konsummsi Sayur Dan Buah Di Masyarakat Dalam Konteks Pemenuhan Gizi Seimbang. Jurnal Kependudukan Indonesia, III(2), 97-119. https://ejurnal.kependudukan.lipi.go.id/index.php/jki/article/download/171/203

Habiburrohman. (2018). Aplikasi Teknologi Akuaponik Sederhana Pada Budidaya Ikan Air Tawar Untuk Optimalisasi Pertumbuhan Tanaman Sawi (Brassica juncea L.) [UIN Raden Intan]. http://repository.radenintan.ac.id/3227/1/SKRIPSI_LENGKAP.pdf

Hanifah. (2021). Belajar Budikdamber, Yuk! Teknik Budidaya Ikan \& Tanaman Sekaligus Yang Bermanfaat Dan Hemat. 99.Co. https://www.99.co/blog/indonesia/teknikbudikdamber-lele/

Khotimah, K., Helmizuryani, H., Muslimin, B., Sari, M. P., Harmilia, E. D., Ma'ruf, I., Suyatno, S., \& Yani, A. V. (2021). Implementasi Budidaya Ikan dalam Ember untuk Meningkatkan Softskill Guru dan Siswa di SMP N 4 Rantau Panjang, Kabupaten Ogan Ilir. Altifani Journal: International Journal of Community Engagement, 1(2), 74. https://doi.org/10.32502/altifani.v1i2.3549

Machfudz, M., Khoiryah, N., \& Hindarti, S. (2018). Pelatihan Penanaman Prilaku Konsumsi Singkong Dan Responsi Masyarakat. Jurnal Inovasi Hasil Pengabdian Masyarakat (JIPEMAS), 1(2), 119-128. https://doi.org/10.33474/jipemas.v1i2.1516

Rhofita, E. I., \& Chana AW, L. (2019). Pemanfaatan Limbah Jerami Padi Di Desa Garon 
Kecamatan Balerejo, Kabupaten Madiun. Jurnal Inovasi Hasil Pengabdian Masyarakat (JIPEMAS), 2(2), 120-131. https://doi.org/10.33474/jipemas.v2i2.2915

Setijaningsih, L., \& Umar, C. (2015). Pengaruh Lama Retensi Air Terhadap Pertumbuhan Ikan Nila (Oreochromis Niloticus) Pada Budidaya Sistem Akuaponik dengan Tanaman Kangkung. Berita Biologi Jurnal Ilmu-Ilmu Hayati, 14(3), 267-275. https://doi.org/10.14203/beritabiologi.v14i3.2085

Walimbo, R., Wulandari, C., \& Rusita. (2017). Studi Daya Dukung Ekowisata Air Terjun Wiyono Di Taman Hutan Raya Wan Abdul Rachman Provinsi Lampung (the Study of Carrying Capacity of Wiyono Waterfall Ecotourism in Wan Abdul Rachman Great Forest Park Lampung Province). Jurnal Sylva Lestari, 5(1), 47-60. https://doi.org/10.23960/jsl1547-60 